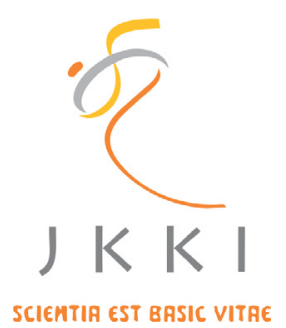

Jurnal Kedokteran dan Kesehatan Indonesia

Indonesian Journal of Medicine and Health

Journal homepage : www.journal.uii.ac.id/index.php/jkki

\title{
Commercializing oocytes in the era of therapeutic cloning; an extension of pro-life versus pro-choice debates
}

Teguh Haryo Sasongko*1

${ }^{1}$ Human Genome Center, School of Medical Sciences, Universiti Sains Malaysia Health Campus, 16150 Kubang Kerian, Kelantan, Malaysia

\section{EDITORIAL}

\section{ARTICLE INFO}

*Corresponding author:

teguhharyosasongko@yahoo.com

Copyright @2018 Authors. This is an open access article distributed under the terms of the Creative Commons Attribution-NonCommercial $\quad 4.0$ International Licence (http:// creativecommons.org/licences/ by-nc/4.0/).
DOI : 10.20885/JKKI.Vol9.Iss2.art2

T herapeutic cloning is the transfer of nuclear material isolated from a somatic cell into an enucleated oocyte in the goal of deriving embryonic cell lines with the same genome as the nuclear donor. ${ }^{1}$ Clinical application of therapeutic cloning would include cell replacement therapy for otherwise incurable diseases such as Duchenne Muscular Dystrophy, Parkinson's Disease, Diabetes Mellitus,etc., without the need for immunosuppressive regimens. This clinical application require the emergence of novel stakeholders in health care delivery, the socalled tissue manufacturers. Due to the nature of cloning procedures, considerable numbers of oocytes should be supplied to produce many different kinds of tissue products that match the market demands. In this situation, oocyte donation on the voluntary basis would no longer be able to cope with the request, especially given the somewhat low efficiency of somatic cell nuclear transfer procedures. ${ }^{2}$ With this, comes the ethical question of whether it is morally acceptable to commercialize human oocytes to keep up with the oocyte demands.

Pro-life proponents would see oocytes, to a certain extent, as seeds of life, though may not be life itself in its fullest meaning. This perspective may be right among religious groups which have been longstanding proponents of pro-life. In this regard, selling oocytes would be seen as disrespect to sanctity of life because it would mean selling seeds of life, if not life itself.

Pro-choice proponents would see oocytes as part of woman's body and thus become woman's possession, over which woman should have full autonomy. In this regard, selling oocytes would be seen as thoroughly an exercise of woman's sovereignty over her own body. The issue could be distinguished from organ commercialization as opposed to donation mainly because of somewhat minimal effects on the physical loss if properly managed.

In the situation where therapeutic cloning has become the norm in medicine, just like antibiotics nowadays, prevention of oocytes commercialization would potentially harm to the practice of medicine, and thus, would do so to many patients in need of otherwise available manufactured cells or organs. This harm would also mean injustice to the oocytes donors that have borne certain extent of medical intervention to obtain their oocytes, while the cells/organs manufacturers enjoy lucrative profits.

Concerns with regards to respect over the sanctity of life should, however, be taken into account, and translated in the form of regulation. A regulatory body should decide on the amount of compensation to women giving their oocytes, in as much as it is enough to compensate to the extent of loss and not to unnecessarily induce women to provide their oocytes, who otherwise would not give. 
Those would prevent harms to medical practice and to patients in that it allows patients to benefit from readily available curative technology. Regulation over the amount of compensation would avoid commercialization in its most extravagant meaning, while at the same time allows justice to women who have given their oocytes.

However, this approach will be confined within state jurisdiction, in that different states may have the different compensatory amount. Compensatory amounts offered by more developed nations could be more attractive to women coming from less developed states. Trans-commercialization of oocytes, which may happen during oocyte shortages in particular countries, may be ethically problematic either allowing or prohibiting it.

\section{REFERENCES}

1. Kfoury C. Therapeutic cloning: Promises and issues. McGill Journal of Medicine. 2007;10(2): 112-20.

2. Akagi S, Matsukawa K, Takahashi S. Factors affecting the development of somatic cell nuclear transfer. The Journal of Reproduction and Development. 2014;60(5). 